\title{
Surviving Genocide, Thriving in Politics: Rwandan Women's Power
}

\author{
Gerise Herndon \\ Nebraska Wesleyan University \\ Shirley Randell \\ SRIA Rwanda Ltd
}

\begin{abstract}
Rwandan women have given their nation new status as a world leader in gender equality, having achieved a 56 per cent majority in Parliament. Women have reached this level of political power for many reasons, including the current government's political will and women parliamentarians' conscious decision to emphasize precolonial traditions of leadership as an alternative to prevailing patriarchal notions of women's capacity. Highlighting women's historical roles as behind-the-scenes advisors effectively promoted gender equality in the public sphere. Not only have women in Parliament taken leadership in promoting laws that protect women against gender-based violence, but also civil society organizations have participated in rebuilding and unifying the country following the trauma of horrific sexual violence and killing during the 1994 genocide. Interviews conducted in Kigali and Butare in 2009 and 2010 inform this study of perceptions of women's power at the parliamentary and the grassroots levels. Women's visibility in national government has not immediately translated into empowerment in the home, in agriculture, in the office or in social life. Formal education is central to providing girls and women the tools to analyze and dismantle remaining obstacles to gender equality in the professional, social and private spheres, building on their political achievement.
\end{abstract}

\section{Strategic Essentialism for Social Transformation}

In discussions of gender equality and representation of women in government, researchers typically cite three countries as exemplary: Canada, Finland and Sweden. Sweden, however, can no longer boast the highest global female representation in Parliament. On 18 September 2008, Rwanda, a country associated by most Western nations with the 1994 genocide against the Tutsis, overtook them all by electing a Parliament comprising 56 per cent women. Many people remain unaware that Rwanda has advanced significantly in terms of gender and power, specifically in terms of the number of women in elected political positions. An investigation of how women came to hold these visible positions of power reveals that women in the ancient Rwandan monarchy held advisory roles that could inspire current women leaders. Indeed, even before the genocide, the Rwandan Patriotic Front (RPF), Rwandan's most powerful political party, promoted gender equality in leadership. Examining Rwanda's complex (and contested) history, women's experience of sexual victimization during the genocide, and the role of women's grassroots organizing can add dimensions to other countries' understanding of how Rwandan women came to hold more public roles. 
In order to achieve equitable representation, it takes more than 'adding women and stirring' (Kilgour 2007, p. 751). Great violence, such as experienced in Rwanda, has the potential to show the need for radical change. In addition, the realization that the Belgian colonizers redefined and reified the largely constructed differences between Tutsi, Hutu and Twa caused some women's organizations and government officials to search their collective memories of Rwandan tradition prior to Belgian imperialism. In seeking solutions to the trauma resulting from the genocide, some Rwandans began to argue that women, especially mothers, had an honored place in pre-colonial history and there was huge potential for them to take peaceful leadership roles in contrast to the male violence of the genocidal regime (Uwineza \& Pearson 2009). Of course, some women played active roles in the preparation and implementation of the genocide, but politicians chose to emphasize instead women's revered roles as mothers in order to bring about sweeping social transformations. What may appear to be essentialism is in fact a conscious rhetorical strategy to use comforting imagery to pave the way for radical change. Rwandan politicians’ canny use of traditional images of motherhood made social transformation possible. It is to be hoped that other countries do not need the violence of genocide to realize the importance of gender sensitivity and the benefits of the participation of women's organizations in civil society.

\section{Methodology: Engaged Listening, Invested Analysis}

Both authors have lived in Rwanda: one has worked for seven years, first as the senior gender, education and governance adviser for the Netherlands development agency (SNV), then as the founder and director of the Kigali Institute of Education (KIE’s) Centre for Gender, Culture and Development (CGCD), and still continues to reside in the country; the other worked as a visiting researcher during a sabbatical year. Following the feminist principle that advocates for interviews as an important method to amplify voices of those otherwise unheard, our project included interviews with Rwandan women and men who hold leadership positions in government as well as in both local women's grassroots movements and international non-government organizations (NGOs) working in Rwanda.

The authors acknowledge that the idea of "giving voice" is problematic. This notion is well explained in "Can the Subaltern Speak?” by Gayatri Spivak who shows the risk of “appropriating the other by assimilation” (Spivak 1988, p.20). Trinh T. Minh-ha signals similar concerns in her documentary Reassemblage. She carefully sidesteps a claim to 
authority when making the film in Senegal by stating in the voiceover, "I do not intend to speak about/just speak nearby.” In reporting this study, we would like to speak “nearby” Rwanda. Clearly, the very presence of researchers listening or recording may influence the evidence observed. Gluck and Patai in Women's Words (1991) advocate the necessity of ethical listening, acknowledging the power relations between interviewees and interviewers. Recognizing the complications and limitations of such ethnographic research, we add our contributions to the myriad voices analyzing gender and power in Rwanda. Our methodology includes qualitative, in-depth, semi-structured face-to-face ethnographic interviews. The authors speak French but do not speak Kinyarwanda. Participants gave informed consent to be interviewed, some in French, some in English and some in Kinyarwanda through interpreters. Some interviews and email exchanges were conducted with a promise to maintain confidentiality, and the names of interviewees or writers are withheld by mutual agreement.

Written texts consulted include email communications from members of the Rwanda Association of University Women. Given the authors' substantial investment in higher education in Rwanda and work for gender equality, our interests have shaped the research conducted. Many of our contacts have been made through university and government colleagues. Thanks to referrals from Prof. Chantal Kalisa and Prof. Rangira Béa Gallimore of the Interdisciplinary Genocide Studies Center (IGSC), a few of our sources have little formal education and live in rural areas. However, many of the research participants are urban residents of Kigali with formal university education and, in some cases, are government officials. Government employees have understandably emphasized a positive vision of Rwandan government initiatives. Many Rwandans have experienced the phenomenon of being “studied” by foreigners and rightly ask why they should trust interviewers. Indeed, the authors have attempted to avoid the extraction of knowledge (comparable to the extraction of mineral wealth) that does not benefit local organic intellectuals; we attempted to use our research to begin conversations that have turned out to be ongoing relationships. By avoiding ambitious claims of objectivity or authenticity, we hope to avoid epistemic violence.

\section{The Ideological Battleground of the Body}


To understand the contemporary position of women in Rwandan society, we begin with a discussion of how women's bodies were subjected to symbolic and very real physical violence and how these dreadful experiences gave rise to solidarity and empowerment.

Sexual violence is a major weapon of war, and mass violence has certainly been the experience of many Rwandans, at least since the pogroms against the Tutsi began in 1959. One important manifestation of Rwandan women's power reveals itself in women's organizations' empowerment of survivors of sexual assault by soldiers and militia. ABASA (We are all the same), is an association of 60 women who were raped during the genocide. The association grew organically from genocide survivors who had no one left but each other and includes both Tutsi women and Hutu women who had been married to Tutsi men. As targets of the genocide against the Tutsi, these women experienced war in their bodies through sexual assault as a weapon of war and a war crime. Rangira Gallimore, originally from Rwanda and currently a professor at University of Missouri, has worked for years with the women of this collective. She cites the testimony of the oldest woman in the collective (Gallimore 2009), who changes the formula of traditional storytelling when expressing the horror of women's experience of the genocide:

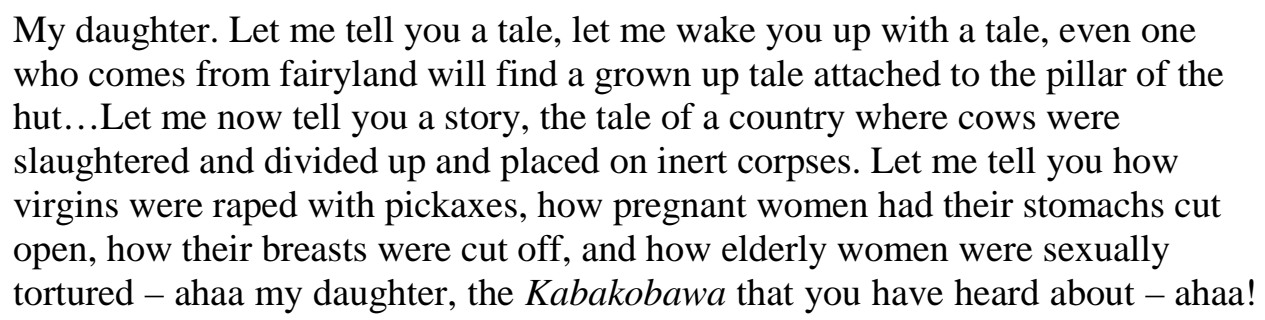

According to Gallimore, the Kabakobawa is a particular location on a hill where girls would receive sexual education. The sound 'ahaa!' indicates a taboo or horror that words cannot describe. Because of the near impossibility of even naming the heretofore-unimaginable violence, we may never know the extent of the atrocities visited on women as part of the genocide.

Rape survivors' testimonies show how either being identified as or associated with Tutsis served as a justification for rape and torture. At Nyamata, where Tutsis took refuge in a church, a group under the auspices of the IGSC heard the testimony of a boy who had survived the massacre of the militia by pretending to be dead (IGSC Nyamata site visit 2009). He told of the Hutu militia, the Interahamwe, torturing refugees they found in the church. He 
witnessed the militia asking a pregnant Hutu woman, 'Why are you here?' She said, 'Because my husband is Tutsi.' They responded, 'No, we mean what you have inside you?' and they cut open her stomach, ripped out the fetus and drove a spear up her vagina. Tutsi women's perceived threat stemmed partly from the mythology that they 'reproduced the alien other' (Baines 2003, p. 487). Of course, many raped women did not survive.

Colonial ideology had promoted the notion of Tutsi women as more aesthetically pleasing because of imagined similarities to European features. This perceived division between imagined ethnic groups is part of the larger whole of genocide ideology, but women suffered rape as a hate crime in particularly brutal ways that men generally did not. The imagined difference between Tutsi women and Hutu women, however, was indeed mythical: 'Eight young men did bad things. I couldn't breathe...After raping me, they told me: 'We thought Tutsi women were different but we found they are just the same’' (Nowrojee et al. 1996, p. 51). 'They said they were raping me to see if Tutsi women were like Hutu women' (Nowrojee et al. 1996, p. 42). Thus, the desire to explore perceived radical sexual otherness appears to have influenced the Interahamwe's violence: militia members desired 'to see how Tutsikazi [Kinyarwanda word for Tutsi woman] look inside' (Nowrojee et al. 1996, p. 47). One survivor whose testimonial appears in The Men Who Killed Me quotes a rapist who wanted to 'see what Tutsi sex looked like' (de Brouwer 2009, p. 60). Another tells how Interahamwe said 'they wanted to kill us but first they wanted to 'taste' a Tutsi woman' (2009, p. 133).

Some of these Hutu women of ABASA had been told by rapists during the genocide to do what they used to do with their Tutsi husbands. Rapists assumed that these Hutu women had somehow learned distinctive sexual practices of Tutsis. Their assumption illustrates the prevailing construction of biological ethnic difference, because, according to Gallimore, sexual education for Tutsi and Hutu women was the same - the bodies of Tutsi women became a specific battleground, a space where rapists claimed victory, an 'expansion of ethnic territory by the male conqueror' (Handrahan 2004, p. 437). Perpetrators obeyed the order to destroy the physiological capacity of 'the Tutsi' to reproduce themselves. These accounts merely hint at a tiny fraction of the horror experienced by women (including Hutu and Twa women). Even if, in the traditional wars of ancient Rwanda and other East African countries, women from the conquered side were taken for forced marriages or servants as a 
sign of victory, they were not killed or subject to the shocking acts carried out during the genocide $^{1}$.

\section{Women's Post-Conflict Identities: Difference and Equality}

Women were more often targeted for sexual assault than male survivors, yet because women were kept alive to be sexual slaves for the militia, more of them survived the genocide than the men. The population in 1995, immediately after the genocide, was estimated to be 60 to 70 percent female with 90,000 men in prison (Paxton \& Hughes 2007). Prior to the genocide, women had been able to participate in political and economic life provided that their maternal role was not threatened (Baines 2003). Given the demographic imbalance after the genocide, women and even girls stepped up to take on roles as heads of household, community leaders and financial providers, addressing the needs of devastated families and communities. Elizabeth Powley (2005) argues that the genocide forced women to think of themselves differently, and in many cases to develop skills they would not otherwise have acquired.

Suzanne Ruboneka (2009), former Executive Secretary of Pro-Femmes/Twese Hamwe, an umbrella organization for women's non-government organizations, attributes greater agency and intentionality to Rwandan women. In a personal interview, she cites their desire to work together to organize and influence the government. Women saw their commonalities, as in the collective where both Tutsi and Hutu women make what are now sold as 'Peace' baskets by Macy's, a US-based department store. Why peace? Because the women who had been abandoned by everyone found each other: survivors and wives, mothers, daughters and sisters of victims came together with wives of perpetrators, who were also victims in a sense. Many of them, like the members of ABASA, had no-one left in their families, so they worked together. Formerly, they may have been identified as either Hutu or Tutsi, but now they publicly insist that they are all Rwandans, have all suffered from the genocide, and must abandon politically constructed differences to continue to survive and thrive.

Some Parliamentarians tend to argue that the roots of women's post-genocide power are precolonial, and that politics, rather than culture, manifests social transformation. Still, we should be aware that Réseau des Femmes and two other women’s organizations came

\footnotetext{
${ }^{1}$ Some men were also victims of sexual assault: see the narrative of Faustin Kayihura in de Brouwer (2009). According to de Brouwer, Hutu women raped men and boys (2009, p. 17), and men were subject to genital mutilation and were forced to rape (2009, p. 15). Unfortunately, studies of male survivors of sexual assault present monumental challenges given the even greater social stigma attached to men as rape victims.
} 
together in 1986 to form Pro-Femmes, well before the 1994 genocide, so even grassroots political organization has pre-1994 sources. Women across Africa who attended the 1985 United Nations International Women's Conference at the end the UN Decade for Women, including Rwanda, were radicalized into action when they returned to their countries. In Rwanda additional women’s NGOs were established and flourished.

After 1994, Rwandan women in NGOs had urgent motivations to lead the country in reconciliation and reconstruction efforts. Looking in from other cultures, many observers respond with admiration for Rwandan women's resiliency and strength. Are they resilient? Or simply choosing survival? Genocide was, according to Esther Mujawayo (2004):

'L'insupportable. Mais insupportable pour qui? Pour moi? Mais non, moi je n'ai pas le choix de me poser une telle question. Pas le choix de trouver cela insupportable puisque je dois le supporter, pour mes filles, qui, elles, doivent vivre...Nous avons été condamné à vivre' ${ }^{2}$.

Perhaps, as Chantal Kalisa (2009), scholar of aesthetic responses to the genocide, has suggested, in personal communication with one author, that what those from other social formations see as amazing strength is merely a sense that survivors are doing what is necessary if they are to live. The other choices would be death or insanity.

As Mujawayo (2004) indicates above, responsibilities to children, whether biological or adopted, may have given some survivors the will to live. Rwandan women's elevated image as mother has enormous cultural importance and has contributed to their political success. Women are powerful symbols of healing and rebirth, especially birth (note the 4.8 fertility rate in $2012^{3}$ ). The status of mothers and importance of motherhood are referenced at all social levels. Interviewees expressed disbelief and pity when one of the authors revealed that she had chosen not to have children. At INEZA ${ }^{4}$ a sewing cooperative of women who have publicly declared their HIV-positive status as a result of the genocide, one survivor in particular testified to the honor associated with being a mother. One survivor spoke with anguish about having lost her title as a mother when her children were killed during the

\footnotetext{
${ }^{2}$ All English translations of the French quotations in the text are by Gerise Herndon, unless otherwise attributed. 'Unbearable. But unbearable for whom? For me? No, I didn't even have the choice to ask myself such a question. I had no choice to find it unbearable because I have to bear it for my daughters who must live...We were condemned to live.'

${ }^{3}$ Using the data from the Demographic and Health Surveys, Rwanda has seen an overall decline in fertility from a total fertility rate of 8.5 in 1983 to 5.5 in 2007/8 (Hartwig, R and S Randell, CGCD Occasional Research Paper 2, KIE, 2010:7) and in 2012 to 4.81 (CIA World Fact Book, in https://www.cia.gov/library/publications/the-world-factbook/index.html).

4 'Doing good when it is needed' or 'A good deed in need' (Trans. Frank Mugisha). INEZA, like ABASA, is a grassroots cooperative that came together organically and is governed by consensus.
} 
genocide. For example, Mama Emmanuel would be the title of a woman whose oldest child is named Emmanuel. She was able to regain her status when a sister 'gave' her a daughter and the survivor was able to take in her niece as her own child.

A vital study of women's political power pre- and post-genocide shows how indigenous tradition provided a special status for mothers:

Social taboos and traditions arose to reinforce respect for motherhood and to protect women and children from danger or abuse....A woman's family and inlaws would pamper and exempt her from certain chores during pregnancy and immediately after delivery of a child. On some occasions, chiefs would punish men who did not conform to these expectations. In poor communities, neighbors guaranteed a steady supply of milk to a woman who delivered a baby (Uwineza \& Pearson 2009, p. 11) .

The special position of mothers in pre-colonial Rwandan society meant that their power to create, carry and bear new life deserved a particular kind of respect. While those outside Rwanda may initially analyze such reasoning as essentialist, the veneration of the idea of motherhood among Rwandan men and women of all classes cannot be overstated.

Rwandan women's place in history is exemplified by the role of the queen mothers who advised their husbands and sons. According to the late Aloisea Inyumba, Rwanda's first Minister for Gender and Social Affairs and a distinguished Parliamentarian, ${ }^{5}$ even in nonroyal families, women in Rwanda had power:

Rwandan history and tradition provide pre-colonial examples of women's power. We had traditional family structures long before we came under colonial leadership. Men could not make major decisions in the home; for example a man would not give away land or cows without consulting his wife. The family tradition is one basis of dialogue with women. (Inyumba 2009)

While some researchers question women Parliamentarians, asking, 'Where did you get this idea about gender from? Is it from Sweden?' Inyumba, in a lecture to the IGSC in 2009, notes that ideas about gender came from within Rwanda, not from outside: 'The leadership of Rwanda has always been aware of the importance of identifying women as true actors in the transformation of our country Rwanda. Therein women’s roles as key advisors in decision-

\footnotetext{
${ }^{5}$ The late Aloisea Inyumba was one of the three women among the eight Commissioners leading the Rwandan Patriotic Front when it was still a rebel group fighting the country's genocidal government. She was the Commissioner for Finance and responsible for raising funds and other support from the Diaspora. When she died in 2011 she was Minister for Gender and Family Promotion.
} 
making inform their ascension into current government posts'. Such analysis counters arguments that often arise when notions of gender equality appear to be imported from the global north rather than indigenous to the local cultures and region.

Government ministries and agencies, such as the Ministry of Gender and Family Promotion (MIGEPROF), the Ministry of Finance and Economic Affairs (with its gender budgeting office), the National Women’s Council, the Gender Monitoring Office, the Rwanda National Police (with its gender desks) and the Rwandan Women's Parliamentary Forum (RWPF) offer a visible commitment on the part of the Rwandan government to gender equality. Women parliamentarians initiated what might be considered a feminist process of sensitizing their male colleagues by inviting them to listen to voters and making them aware of genderbased violence (GBV) before crafting the GBV law. According to Pearson and Powley's Demonstrating Legislative Leadership, 'women have improved dialogue between the grassroots and national levels, enhanced collaboration between civil society and the government, demonstrated legislative leadership and advocated for human rights' (2008, p. 6). The attempt to unify the higher levels of government with civil society conforms to the postgenocide nationalist discourse aimed at erasing perceived ethnic divisions among Rwandans.

National unity, the important concept that 'We are all Rwandans,' is tied to gender unity. The late Inyumba spoke of the necessity of such post-conflict unity (2009):

\footnotetext{
After five years, there was a general agreement in the country that no one will be discriminated against because of their identity...the guiding program for Rwanda...was unity and reconciliation...We are keeping men and women working together. We are not going to advocate for a certain women's agenda, but rather use a mainstreaming approach.
}

Each advocate for gender sensitivity stresses the importance of working in partnership with men. Indeed, the fact that Pro-Femmes includes the Rwandan Men's Resource Center (RWAMREC) under its rubric is a testament to women's recognition of the necessity of men's collaboration and input towards achieving gender equality. Rwanda is now making considerable progress in involving men in this endeavor, using targeted methods of engagement with male leaders both at national and village levels (Carlson and Randell, 2012). 


\section{Men's Post-Conflict Perceptions}

Given that gender mainstreaming and full partnership with men must be part of any gender analysis in Rwanda, men's perspectives necessarily inform any balanced analysis. One male interviewee expressed the perception that the family structure had been affected by the genocide and women needed special attention. Another interpretation claims that men's governance has been fraught with violence, so perhaps women can govern in a different manner. The (male) former justice minister and current minister of the National Commission for the Fight against Genocide, Hon. Jean de Dieu Mucyo, explained in an interview (2009): 'Men managed badly. We are trying to see if women succeed where men failed. Some say genocide is the fruit of the power of men.' While this view remains open to debate, it is consistent with the idea that the entire society needed fundamental transformation following the devastation of 1994.

Parliamentarian Hon. Berthe Mukamusoni remarks that women’s strength during the genocide made an impression on men. She said, 'Men and women both took part in the fight against the genocide, even at the front. When the men saw how tough the women were, healing the sick and cooking the food, as well as their presence at the front, they saw what women were capable of and the value of collaborating with them' (Women for Women International 2004, quoted in Paxton \& Hughes 2007, p. 175). Stereotypes about women’s weakness or emotional vulnerability were belied by the RPF when 37.5 percent of their leadership during the struggle was female. Efforts towards gender equality did not emerge only after 1994; RPF's conscious effort to promote women's leadership was a priority well before the genocide.

Women's new political visibility provides evidence of Rwanda’s social transformation. Hon. Jean de Dieu Mucyo, in response to a question about whether Rwanda had undergone social transformation (2009), used women as an example:

You see the position that women were in before and that they are in now and you can see real social change. The resistance to change was strongest, or the change took longest, out in the country. Men believed that having women in charge was a bad idea, that female-headed households weaken the family and the society, but now they are beginning to see that women can lead.

This interpretation holds that out of great violence, fruitful change can emerge. Rwanda has banished archaic patriarchal laws still enforced in many African societies, such as those 
permitting polygamy and those that prevent women from inheriting land. Thanks to RWPF, the legislature has passed a GBV law aimed at ending domestic violence and child abuse.

A member of the Liberal party and the chair of Parliament's Human Rights Committee speculates on reasons for women's particular experiences that may make them better equipped to occupy positions of power in Rwanda:

More than men, women are the victims of the war. They have different priorities to those of men. They have more concern about issues related to violence in general, and gender-based violence in particular. Women have faced discrimination so they want to put a stop to discrimination. All of this will contribute to preventing another genocide. (Hon. Evarist Kalish MP, quoted in McGreal 2008, para. 16).

This frequently expressed opinion is not necessarily essentialist but is based on women's experiences of discrimination and having been singled out for particular sexual violence.

'Real' women, of course, experienced discrimination and violence often differently from men, not because they are fundamentally different, as imagined by the propagandistic discourse, but because their experiences as women influenced their understanding of discrimination. They experienced fighting as soldiers, hiding from perpetrators, fleeing pogroms, rape as a war crime, sexual slavery, the killing of their children - all aspects of the genocide. They experienced these phenomena not only as targets because of their ethnicity or collaboration, but they also experienced them in female bodies constructed as different and potentially maternal, whether they were menstruating, pregnant, giving birth, breast feeding babies, nursing children, going through menopause or caring for the sick and elderly. Their experience has inevitably influenced their lives as women. While few genocide survivors moved on to political roles, many of them continued to struggle in much more fundamental ways. Nonetheless, the devastation of women's experience and the strength shown in their recovery is part of the story of Rwandan women's power, and that story has shaped the perceptions of Rwandan women leaders.

\section{Collectives Creating and Transforming Institutions}

Local women's organizations like Pro-Femmes and AVEGA (Association of Widows of Genocide), contributed to the political process and the writing of a gender-sensitive Rwandan Constitution (Inyumba 2009). Women's participation in civil society has drawn them into 
politics. Women are selected as 'integrity judges’ to administer justice in local gacaca courts (a system of community transitional justice based on traditional, cultural law enforcement procedures), which have proved to be far more efficient and inexpensive than the International Criminal Tribunal of Rwanda (ICTR). While international researchers like Professor Phil Clark (2012) have praised the effectiveness of gacaca courts, they have also been the targets of criticism from international human rights groups as well as some survivors, who question their impartiality and effectiveness. Indeed, some members of INEZA have reported re-traumatization and fear of reprisal as a result of being called as witnesses.

However, the majority of interviewees said they preferred local justice, which they see as more likely to be restorative, to be culturally sensitive, and to lead to reconciliation, than the costly and slow justice administered by the ICTR. Women are perceived as less corrupt and more likely to be seen as having integrity, according to the testimonies of AVEGA members, who pride themselves on serving as a pool for gacaca judges (IGSC AVEGA site visit 2009). What is more, Denis Bikesha, head of the Gacaca Commission, while acknowledging that he has no expertise in gender studies, commented in a personal interview (2009), 'In my experience women are among the best judges.' Similarly, Muhire Bitorwa, (whose wife, a teacher, is helping pay his way through a Kigali University) contends: 'In my view, women are more reasonable, more merciful and less corrupt than men' (quoted in McCrummen 2008, para. 27). These men are careful to qualify their assertions as personal opinions, but such views may be well informed.

The opinions contrast women's rationality, mercy and integrity with the kind of 'justice' enacted by the male-dominated genocidal regime, which was known for corruption before it was known for cruelty. Internationally, one can see these assumptions at work in the elections of Michele Bachelet to the presidency of Chile and Ellen Johnson Sirleaf to the presidency of Liberia - war-torn countries imagine women and mothers as more likely to seek peace. Clearly, multiple counter-examples contest a view that theorists might deem essentialist: the oft-cited military initiatives of Golda Meir, Indira Gandhi, and Margaret Thatcher come to mind. Further, Rwandan women should certainly not be romanticized: they have been convicted both at ICTR and gacaca courts of planning and participating in the genocide.

Part of the reason for public perceptions of women's difference is rooted in strategic political rhetoric about mothers. Just as anti-rape activists appeal to masculine notions of protection to 
stop rape (every female is someone’s mother, wife, sister, or daughter), so politicians successfully use the rhetoric about maternal strength to convince the population that women's leadership adds potential for peace. Given the relative newness of women assuming political leadership in Rwanda, invoking maternal status as indigenous rather than colonial wields rhetorical power. Whether the rhetoric continues to be useful, metamorphoses, or becomes constraining remains a question for further study.

While women's ongoing recovery from violence evokes admiration, the most visible success of Rwandan women is their rise to elected political positions, and their current status as being part of the most gender-equal governing body on the globe. We can see the jump in numbers between 1997 and 2008. Obviously in part because of the demographic imbalance between males and females post-genocide, in 1997, women went from 4 percent to 17 percent representation in Parliament. Post-conflict transformations include a constitutional change in 2003 requiring 30 percent of Parliamentary seats be held by women. In that year, women jumped from 26 percent to 49 percent of parliamentarians, and in 2008 to 56 percent. Rwanda remains the only country in the world to achieve a female majority in Parliament. Incidentally, Rwandan Parliamentarians evince surprise upon learning that women comprise under 20 percent of the U.S. Congress.

In addition to the 30 percent quota for women in Parliament in Rwanda, the transitional government established the Ministry for Gender and Women in Development as well as gender posts in all other government and ministerial bodies in 2003. These bodies are charged with ensuring 'gender sensitivity' in all policies. It was the women Parliamentarians who made certain that laws against GBV were passed. What is more, women Parliamentarians were instrumental in advocating and lobbying for the Inheritance and Marital Property Law Rwanda in 1999, giving women property rights, including the right to inherit land from their parents (World Bank 2008). Nonetheless, constant vigilance is necessary. For example, the passing of the recent Labor law [REF] reduced the maternity leave allowance for working women. Given the difficulties faced by mothers working fulltime in the formal sector and given the absence of discourse about families other than heterosexual, it can be concluded that the special status of mothers does not include all manifestations of parenting. Those who parent outside the sanctioned boundaries of heterosexual marriage or those who adopt rather than give birth to children with the parents' DNA, reveal noticeable lacunae in public discourse. 
Indeed, rather than a concept of traditional maternal power, more immediate and urgent matters called women to work for their country following the genocide. One Parliamentarian spoke of her sense that she needed to run for office:

Mais le Rwanda avait besoin d'un cadre administratif et politique, aussi simple soit-il, pour redémarrer un semblant de vie, soigner les malades, envisager la reprise des écoles, imaginer rendre justice, etc. Il fallait imaginer de nouvelles lois et un travail au parlement a fini par me sembler tout à fait nécessaire (Mukankomeje 2009, p. 361) ${ }^{6}$.

Under a Norwegian Government-funded program 'We Can Do It', preparation of candidates by Pro-Femmes includes teaching women how to respond to questions, how to dress and how to respect 'time' (the word ‘time' was spoken in English during the interview).

Returning refugees from the Rwandan diaspora have also taken key positions among officeholders. The outstanding public performance of women Ministers holding senior positions in Cabinet, for example, Foreign Affairs, Health, Agriculture, Infrastructure in 2012, has altered perceptions about female office holders: women are perceived as 'more approachable and trustworthy politicians than male counterparts' (Remmert 2003, quoted in Powley 2005, p. 25). This perception may not be because women are fundamentally different but as Stolberg (2011) notes regarding the relative dearth of scandals among women politicians in the United States: " "I have no hard evidence that women are less likely to engage in risky or somewhat stupid behavior,” Ms Pearson [University of Minnesota expert on U.S. Congress] said. "But women in Congress are still really in a situation where they have to prove themselves to their male colleagues and constituents.”' Women's political power remains open to additional scrutiny and thus women police their own public behavior in ways that male officeholders may not.

\section{Women's Economic Promise}

While women's ability to survive trauma and to thrive in politics is striking, enormous challenges remain to empowering the majority of Rwandan women. Extreme poverty exists 'upcountry,' or in the countryside. Even when women make money at markets through

\footnotetext{
6 'But Rwanda needed an administrative and political framework, as simple as it was, to start up a semblance of life, to care for the sick, to envision restarting schools, to imagine rendering justice. We had to imagine new laws and working in Parliament ended up seeming completely necessary to me'.
} 
selling agricultural products, those who work in grassroots organizations report that many husbands take control of the money and thus women’s autonomy. However, journalist Anthony Faiola celebrates Rwanda as an 'example of how empowering women can fundamentally transform post-conflict economies and fight the cycle of poverty' (2008, A4). A positive illustration comes from the southern province where the women-only cooperative of ABASA has been highly successful in its work with raising cattle and keeping bees.

Continued barriers to women's financial success include customary traditions in rural areas. Even though laws technically protect women's land rights, 'households headed by women have smaller landholdings than men. Women are also less likely than men to use land for their enterprise development' (World Bank 2008). Yet, because women head more than onethird of households in Rwanda, women in Rwanda are more likely to own land than in some neighboring countries. In 2012, women ran forty-three percent of businesses in Rwanda (Mbabazi, 2012). In a 2008 'Peace through Business' initiative by the Institute for Economic Empowerment of Women, Rwandan women worked with Afghan women to share ideas on how to start and manage a small business. Indeed, U.S. Secretary of State Hillary Clinton cites Rwanda as a model of economic progress, particularly compared to elsewhere in Africa:

In a country that had been ravaged by genocidal conflict, the progress is amazing. It has one of the fastest growing economies in Africa, even in the midst of the global recession...The Rwandan people believed in themselves. And their leaders believed in policies based on evidence and measurable results, including a nationwide emphasis on family planning, crosscutting partnerships with donors and NGOs, and a greater premium on professionalism in the government and the health sector. (2009)

Clinton highlighted the role of NGOs and family planning. Clearly, both in Rwanda and globally, lack of knowledge or power in regard to controlling fertility hinders women's economic empowerment and educational attainment.

But gender-focused NGOs in Rwanda have made important strides in the past 15 years, especially in contrast to what has been possible in other societies in the Great Lakes Region. Anthony Faiola (2008) notes that women have proven to be more reliable when it comes to borrowing, saving and spending wisely:

Women more than men invest profits in the family, renovate homes, improve nutrition, increase savings rates and spend on children's education, officials 
here said...'Rwanda's economy has risen up from the genocide and prospered greatly on the backs of our women,' said Agnes Matilda Kalibata, Minister of State in charge of agriculture. 'Bringing women out of the home and fields has been essential to our rebuilding...We are becoming a nation that understands that there are huge financial benefits to equality' (Faiola 2008, A4).

According to Winnie Byanyima, Director of the United Nations Development Program’s gender team 'We have overwhelming evidence from almost all the developing regions of the world that [investment in] women makes better economics' (quoted in Faiola 2008, A5). Women have proven to be careful investors and stewards - and they are also more likely to pay back loans than male borrowers. Indeed, Faiola cites the opinion that women have more self-restraint and more resilience than men whose credit record shows less success. While the explanation may be open to debate, the fact that women are better investments is not.

\section{Debating power inside and out}

Observing the operation of gendered politics and social power in Rwanda provides immeasurable complexity and limitless ideas for debate. Analysts must acknowledge the limitations of various women's situations in Rwanda through an examination of various sources: interviews, meetings, advocacy, online communications and texts, including investigative reports and academic analyses.

Many respected political scientists from Europe and the U.S. question how much actual power Rwandan women have, despite their apparent numerical power as political representatives. Paxton and Hughes, in Women Politics and Power (2007), argue that Rwanda is an authoritarian state and that the women who have acceded to positions of power tend to be former RPF members. Indeed, non-RPF women appear to have limited access to governance. Burnet (2008) claims Rwanda is an authoritarian single-party state and that women's policy-making power has actually decreased, in part because the most vibrant women from NGOs now work in government, and those who took their places have less experience and capacity. At the same time, she argues that women as heads of household have expanded the boundaries of socially acceptable roles and broadly expanded freedom in career choice. Devlin and Elgie (2008) argue that women Parliamentarians’ policy output is largely symbolic. Many scholars contend that women's power is more image than reality and that women's presence in Parliament has not brought about substantive policy changes. 
Certainly, Rwanda can rightfully be called ‘authoritarian’ using U.S. or even G-20 definitions. Rwanda’s laws against genocide ideology do not allow genocide denial, just as Germany’s laws do not permit Holocaust denial. Granted that Rwanda is not democratic by U.S. definitions, one may nonetheless question the extent to which U.S. understandings of democracy can be effectively implemented at this point in Rwanda's recovery from near destruction a mere 19 years ago. Inyumba (2009) argued that democracy for Rwandans is about social transformation: 'Working for the welfare of our people is the best democracy, not the cosmetic version of elections.' That is, democracy includes giving people jobs, electricity, Internet access, and safety.

In addition, the current government has emphasized gender equality and has strategically showcased women's apparent political success. Interviewees often cited political will and good leadership as vital to Rwandan women’s political ascendancy. Pragmatically, the push for women's visibility in government may be partially economic rather than purely democratic. That is, any economy that does not take advantage of the creativity and potential of over half the society hurts its opportunities for improvement. Women's leadership roles may offer strategic arguments for further economic investment from donors. Even if women's political power does not coincide with U.S.-style democracy, women's visibility may serve as inspiration for girls throughout the country to strive for leadership positions they might not have considered without women role models. As Burnet indicates, even if women's narrowly defined political efficacy is questionable, women's possibilities for professional careers and social roles have expanded and improved dramatically.

In Rwanda, there is a history of women participating in decision making at all levels and women members of Parliament are by no means token leaders, having come through the leadership ranks at village, cell, regional and national levels. For example, the Minister of MIGEPROF, Oda Gasinzigwa, appointed in 2013 had both NGO and government experience before taking up her position. She was first an elected member of a cell women's council, went on to be a member, then President of RNWC, and was the first director of the Gender Monitoring Office before taking up her Ministerial position.

In recent debates on the mailing list members of the Rwanda Association of University Women (RAUW) provide insight to critics of Rwandan women's power. Those RAUW members cited below are either Rwandans or long-standing residents who have at least an 
undergraduate degree. One member insists on the specificity and complexity of the Kinyarwanda language. Just as those who did not understand the meaning of 'go to work' and 'cut down the tall trees' prior to the genocide were not able to see the planning of the genocide underway, those who do not speak Kinyarwanda cannot fully understand the culture. How many scholars consider what is lost in translation? She writes in an email to the RAUW listserve on 10 June 2011: 'Firstly: it is a big mistake by the international community wanting to make themselves experts in all local situations - Rwanda is Rwanda and basically better understood by Rwandans. A lot is hidden in our language and culture that may not be easily understood by outsiders.' What is perceived as authoritarianism may be called "strict” or “strong” leadership, or "political will,” within the country; such leadership is sometimes perceived as necessary for a small country (especially one so recently devastated by widespread violence) to compete with larger, wealthier and more industrialized countries.

Another scholar of gender argues that what we may assume is repression may in fact be selfcensorship by local media and agencies striving to project the image of success. She also advocates distinguishing between policy and implementation. In an 8 June 2011 email to the RAUW listserve, she explains some of the nuances of civil society interactions with government: 'There is little overt political repression in Rwanda but quite a lot of selfcensorship by the media etc. There are policies and programs in place to build a strong civil society and citizen engagement. These need to be strengthened.' While international human rights organizations and some scholars emphasize Rwanda’s authoritarianism, Rwandans with formal education argue for awareness of cultural particularities and better implementation of existing policies.

Even Rwandans who believe that woman do hold authentic political power do not necessarily agree with the current provision that 30 percent of Parliamentary seats should continue to be reserved for women. Privat Rutazibwa, a journalist and media analyst, contended in a 2009 lecture to IGSC that the quotas for women in leadership positions should end: 'Toute cette politique des quotas risque d'infantaliser les femmes qui ont besoin de ce pourcentage. Cette politique doit être conditionnelle, pas permanente. ${ }^{7}$ But the 30 percent requirement does not mean electing women just because they are women. In response to the 2008 election results, Gasinzigwa, then RNWC President said: 'Our aim is not having 70 percent or 80 percent

\footnotetext{
${ }^{7}$ All these politics of quotas risk infantilizing women who 'need' this percentage. This policy should be conditional, not permanent.
} 
representation in Parliament, as people may think... What we care about is competent women with appropriate capacities — and those who were elected have that capacity' (UNIFEM 2008). Women do not want charity or even affirmative action - some women Parliamentarians, in fact, voted against university admission standards for women that were different from those for men.

\section{Sugar and Salt, Poverty and Pads: Challenges to Equality}

Of course, women's capacity generally lags behind that of men because of barriers to formal education. A male university student revealed in conversation the perception that women in Parliament had lower educational levels than their male colleagues (Personal Interview February 2010). A RAUW member demonstrates some of the challenges that women face:

The statistics of the elections show that majority of the women elected in Leadership have $\mathrm{A} 2^{8}$ or below $\mathrm{A} 2$ education. In the villages probably men have the same level of education but at other levels women might not even have the guts to open their mouths because of their level of education (Email message to listserve 8 June 2011).

Because of this persisting inequity, members of RAUW and KIE researchers researched the reasons girls fall behind in many educational contexts with the aim of addressing the obstacles. Prof. Grace Verdiana Masanja of National University of Rwanda (NUR) has documented some of the disparities, demonstrating that gender mainstreaming in formal education remains an unmet goal for the nation:

The gender gap within the research and academic ranks is still very wide ... among the $377 \mathrm{PhD}$ holders in Higher Education Institutions in Rwanda only 32 ( $8 \%$ in the category) are women and among the 1,159 masters degree holders in the country, women are 210 (18\% in the category) (Source HEC - Higher Education Council).... The proportion of women in research teams is low in general and mostly they occupy junior positions. Only 3 out of 70 research grants projects that have received funding through the NUR Research Directorate since 2003 are led by women, and of the 21 Post Doctoral grants only 3 have gone to women (Masanja 2010).

Education and training are key for candidates for political office. At a meeting of the Norwegian People’s Aid evaluation of the We Can Do It (WCDI) training program, Dinah

\footnotetext{
${ }^{8}$ Education in Rwanda is generally modeled on the British system, thus A levels are studied between the ages of 16 and 18. After A1 is completed, A2 is the stage prior to applying to university. A-level students take three subjects and thus focus their education more narrowly than students in International Baccalaureate programs.
} 
Musindarwezo (2010) indicated that the country still needs to avoid essentialism in filling positions such as appointing women only to gender-related posts. Nonetheless, Rwanda should not assume that female candidates are fundamentally and essentially different from male candidates or that just because a candidate is female, she has the necessary training, expertise and gender sensitivity to perform well. The Needs Assessment report for WCDI includes the following recommendation:

Men should be engaged in the WCDI so that they come on board to support women's participation in politics instead of becoming obstacles to women. It was discussed that WCDI is a women empowerment program, however it was agreed that men can be brought on board during local actions (Musindarwezo 2010).

Hence, there are dangers in essentialist assumptions about innate qualifications of biological females. It bears repeating that Rwandan women's lived experiences shaped by social expectations and discourse of a patriarchal culture (though, some would argue, a matrifocal history) informs their view of how they came to power and why they have the necessary capacity. Rwandan Parliamentarian Henriette Umulisa (2010) noted that while, in her opinion, women have power behind the scenes in managing the household, many could not have succeeded politically without the support and involvement of men.

Jefremovas (2002, pp. 84-5) argues that Belgian control diluted the traditional power of women in their roles as wives and mothers. Other scholars debate how much actual power Rwandan women possessed historically. Recent research questions to what extent indigenous culture meant real power for women:

By insisting that Rwandan culture is rooted in values that support women's rights, women Parliamentarians - and their male allies - explicitly and successfully used cultural arguments to build a constituency around a modern political reform. Rather than focusing on dramatic cultural shifts that enabled women's political participation and highlighted the need for change, the women leaders argued that a continuity of cultural tradition supported their efforts (Uwineza \& Pearson 2009, p. 16).

That is, some of the references to pre-colonial women's power may exemplify more rhetorical savvy than balanced historical research, which may well demonstrate that the colonial era built on existing gender divisions based on the gender stereotypes in patriarchal societies everywhere. 
Contrast women's public power with women's private lives and roles at home in Rwanda, and we find women working a second and third shift, lack of family planning, poverty, lesbian invisibility, and patriarchal ideology, especially in rural areas. Many individuals who work in NGOs, both male and female, confirm that while women have political visibility, they do not have social power in the spheres of the home or the workplace. The roles of wife, mother, and household manager matter greatly at home, but women differ in their opinion of whether those roles confer power or bespeak servitude. Poorer women do all the cooking, the cleaning, and other household chores in addition to much of the agricultural work. Even if women earn money by farming and selling produce, many men still manage the money. Generally, upper-class women must make sure the household is in order while men sit and wait to be served.

A professional woman told one of the authors during an interview that, in spite of her husband's higher education, he expects to be served like royalty: 'I am A to Z, I am sugar and salt, I am soap, electricity and rent - and what do I get out of it? That is gender in our country' (Personal interview 2010). This same interviewee responded to a question about what rural women think of women in Parliament: 'They don’t know what Parliament is.' The lack of perceived relevance between the poverty and customary practices in rural areas and the rhetoric of gender equality in more urban areas remains a persistent challenge for Rwanda's lawmakers. Despite excellent laws against GBV crafted and implemented by Rwandan women Parliamentarians, of course women of all classes and all locations experience domestic violence, just as they do in every other country. Only one women's shelter exists in Rwanda; what is more, wives are expected to suffer in silence, to try to save their marriages rather than bring the perception of public shame to their families. In addition, there are challenges with the implementation of the GBV law.

After poverty, GBV might be the most serious of inequalities that Rwandan women face. Yet another on-going challenge is the extent to which women at all levels of income and education are unaware of their rights. As in many African countries, women do the majority of agricultural labor, but despite international conventions such as the Convention on the Elimination of All forms of Discrimination Against Women (CEDAW), women often do not own the land they work - or if they do, they may not be aware of their inheritance and property rights. As with GBV, excellent laws exist to protect women (the 1999 Inheritance and Marital law, reinforced by the new Constitution in 2003 and the new Land law on 
property in 2005). The 1999 law gives a woman the right to inherit her husband's land if the couple’s prenuptial agreement recorded husband and wife as co-owners. Nonetheless, many fail to take advantage of pre-nuptial agreements because they cannot afford them. Thus, in divorce cases, women have no legal evidence that property was jointly owned in practice. De Brouwer notes that despite excellent laws permitting women's land ownership, it remains a struggle for women to own farming assets (2009, p. 148). Consequently, the ideal expressed by the legal system is rarely a practical reality.

Concerning the laws against GBV, admirable attempts to communicate women's rights have been made by government agencies as well as by Pro-Femmes, RWAMREC and other NGOs, yet only a small percentage of rural and village women have access to this training. As the MIGEPROF notes, 'It is a good idea to enact laws, but it is better to make them known by beneficiaries.' A 2005 study indicates that 31 percent of Rwandan women have experienced GBV from a partner or husband (Rwanda Demographic and Health Survey 2005). Most women cannot leave their work at home, whether with children or on the farm, to attend the kinds of training sessions that make them aware of their rights - if their chores are not completed at the end of the day, men may batter them. Thus, they may not be fully aware of the newer laws against GBV and women's rights to property, especially if they get divorced. Indeed, interviewees indicate that GBV is prevalent at all levels, from women Parliamentarians down.

Lucie Nukurundo, formerly of Rwanda Initiative for Sustainable Development, argues that NGOs have made great strides in educating women about their rights. Nukurundo worked against GBV in the rural areas of Ruhengeri, Kabushinge and Gitarama. At the end of a training session to raise awareness, women and men are asked to sign contracts stating that they will not use violence in the family. Women folded up the contracts and tucked them in their pagnes (traditional wrap-around long skirts) so that they could later remind their husbands, if necessary, that they have signed an agreement not to break the law. Nukurundo contends that women who do have access to anti-GBV training inform and protect their compatriots who are not able to attend. She and Emmanuel Kabalisa of RWAMREC argue that they have seen clear progress in changing attitudes about violence and have observed behavioral changes among participants within two months of the training. 
When men and women realize that what they do is defined as violence, they pledge to renounce violence and to inform their friends about what constitutes violence. Kabalisa describes training of men and women in coffee cooperatives in Gisenyi. The workshops aimed to help citizens in rural areas understand and recognize violence. Rwanda has outstanding laws to protect women from domestic violence, employment discrimination and unequal distribution of wealth and property. But there may be a disconnect between the excellent legislation and the reporting or enforcement of that legislation. As in many cultural contexts, domestic violence remains a private issue that women hesitate to reveal for fear of hurting or shaming themselves and their families. Crucial also is the lack of legal protection in terms of implementing the legislation.

Of course, many of Rwanda's challenges to achieving gender equality could be addressed by education. While girls and boys are present in equal numbers in primary schools and fare more or less equally well until age 12, the number of girls drops precipitously during adolescence. According to the 2009 Annual Report of the Centre for Gender, Culture and Development at Kigali Institute of Education, 'girls start dropping out in secondary school and comprise less than 30 percent of students in Rwandan public universities' (Randell, p. 3). Girls' and young women's inequality in formal educational systems is one of many areas of research in progress by the new CGCD at KIE. According to a 9 June 2011 email message to the RAUW listserve, a professor observes the challenges girls face in Rwanda's formal educational institutions:

\footnotetext{
Women's low proportion at undergraduate level in public higher education institutions is based on the selection after their Secondary Advanced level...The average shows the number of female students at undergraduate level is slightly higher than that of male students because the majority are in private HEI (higher education institutions) or in evening programs whose quality generally is not as good as that of public HEI. Women are extremely few at the level of postgraduate studies (Masters and especially $\mathrm{PhD}$ level); also women with such qualifications are proportionately very few compared to men in the country...Now, generally, women in leadership need also to have a sufficient level of education for them to make an impact on the society and to be transformative agents.
}

Because girls tend to fall behind boys, particularly in science and technology education, at around ages 12-14, researchers at CGCD have conducted interviews with girls, parents and teachers to determine the reasons for this decline in performance. Responding to studies that 
indicate that girls begin missing school around the time they begin menstruating, in part because of lack of pads and separate bathrooms, RAUW has conducted an ongoing campaign to break the silence about menstruation. RAUW's hope is to address the stigma surrounding menstruation and remove obstacles that hinder girls' attendance before they leave school altogether.

But RAUW could not have begun its initiative to remove import taxes on sanitary pads without the assistance of researchers educated at internationally recognized institutions. To respond to the disparity between women's numerical majority in government and girls’ lower educational level, more researchers in gender studies need to be trained. Rwanda's Report on Progress towards the Beijing +15 Goals notes that 'many people (including officials) do not understand clearly gender as a concept and planners do not have the required skills to mainstream gender in programs, policies and projects. In addition, there are not enough gender experts in the country, since no university, so far, has a gender studies department' (2009, p. 62). So while gender balance and gender sensitivity are clear goals of the Government of Rwanda, education in gender studies is essential to achieving the reality. Fortunately CGCD at KIE launched its Master's degree in Gender, Culture and Development in 2011, which has graduated gender sensitive men and women at the end of 2012, who in turn can involve others.

\section{Soft Voice, Strong Heart}

Inyumba (2009) argued that promoting women in decision making is inspired by indigenous culture and is upheld by the present leadership. Other countries can learn from both the rhetoric employed to advance gender equality and from Rwanda’s economic progress. Inyumba recounted the following anecdote as an illustration of the current administration's gender sensitivity: 'It is not surprising for a leader to call a male-dominated TV show and say that a program is not gender-sensitive and point out the need for female representation'. Incipient gender mainstreaming can be traced to Parliamentarians' conscious decision to emphasize pre-colonial traditions of leadership as an alternative to prevailing patriarchal notions of women's capacity. Women's civil society organizations have participated in rebuilding and unifying the country and training women candidates following the trauma of horrific sexual violence and killing during the 1994 genocide. 
Those critics who contend that women's presence in Parliament has not brought concrete results neglect the importance of the legislation promoting women's land rights and against gender-based violence (not to mention the inspiration that Parliamentarians have given to local women). Grassroots trainer Nukurundo congratulates the President and the highest levels of government when praising the progress Rwanda has made. One Parliamentarian commented in a personal interview about the president's advocacy for women Parliamentarians: 'When one woman was taking oath in parliament, her voice was so soft that the others could not hear her oath, and some of the men started laughing. The president admonished the men, saying, 'No, behind that soft voice is a strong heart'” (Personal Interview 2010). And in her study on Rwandan women in Parliament, Powley (2009) concludes: 'The Rwandan case provides us with examples of gender-sensitive policy-making and innovative electoral mechanisms that could be models for other parts of the world,' certainly the USA with its 17 percent of women in Congress. To be sure, women's visibility in national government has not immediately translated into empowerment in the home, in agriculture, in the office or in social life. Formal education is key to providing girls and women the tools to analyze and dismantle remaining obstacles to gender equality in the professional, social and private spheres, building on their political achievement.

The documentary about women post-genocide, God Sleeps in Rwanda, takes its title from a Rwandan proverb: 'They say my country is so beautiful that although God may wander the world during the day, He returns at night to sleep in Rwanda' (2005). The beauty is not found only in the hilly landscape, but indeed, in the willingness to use innovative rhetoric in striving for social change and to rethink assumptions about gender. The question remains, however, whether in the next generation, the exalted role of mother which has facilitated such strong engagement in the social and political life of the country will function more like a ladder or a cage.

\section{Acknowledgement}

Portions of this paper were presented at the 'Femmes, Conflits et Pouvoir' conference in Toulouse, France, October 2009. Grateful acknowledgement is given to Meera Bhardwaj, currently a Fulbright scholar in Cameroon, for her research assistance, ideas, and support during the interviewing process in Rwanda. 


\section{References}

Avega Agahozo: Association des Veuves du Génocide - Association of Widows of Genocide, 2009, Interdisciplinary Genocide Studies Center site visit, Kigali, Rwanda, 15 July 2009.

Baines, E.K. 2003, 'Body Politics and the Rwandan Crisis’, Third World Quarterly, vol. 24, pp. 479-93.

Bikesha, D. 2009, Minister of Gacaca Commission and National Justice, Personal Interview. Kigali, Rwanda, July 2009.

de Brouwer, A.M.; Ka Hon Chu, S. (eds) 2009, The Men Who Killed Me: Rwandan Survivors of Sexual Violence, Douglas \& MacIntyre, Vancouver.

Burnet, J.E. 2008, 'Gender balance and the meanings of women in governance in postgenocide Rwanda', African Affairs, vol. 107, pp. 361-86.

Carlson K and S.K.Randell 2013, Gender and Development: Working with Men for Gender Equality in Rwanda. (in press).

Clark, P. 2012, ‘How Rwanda judged its genocide’, Counterpoint, London: New Africa Research Centre.

Clinton, H. 2009, Speech delivered at the 8th Forum of AGOA in Nairobi, Kenya. Retrieved from http://businessinfocus.blogspot.com/2009/08/hillary-clintons-speech-fulltranscript.html

Devlin, C. \& Elgie, R. 2008, 'The effect of increased women's representation in parliament: The case of Rwanda', Parliamentary Affairs, vol. 61, no. 2, pp. 237-54.

Faiola, A. 2008, 'Women rise in Rwanda's economic revival', The Washington Post, 16 May 2008, A01.

Gallimore, R.B. 2009, Lecture to the Interdisciplinary Genocide Studies Center, Kigali, Rwanda, July 2009.

Gallimore, R.B. 2008, 'Militarism, ethnicity, and sexual violence in the Rwandan genocide', Feminist Africa, vol. 10, Militarism, Conflict and Women’s Activism, August.

God Sleeps in Rwanda. 2005, documentary, Acquaro, K. \& Sherman, S. (Dirs), Public Broadcasting System.

Gluck, S.B. \& Patai, D, Eds. 1991, Women's Words: The Feminist Practice of Oral History. Routledge, New York.

Handrahan, L. 2004, 'Conflict, gender, ethnicity and post-conflict reconstruction', Security Dialogue, vol. 35, pp. 429-45.

Hartwig, R. \& Randell, S. 2010, CGCD Occasional Research Paper 2, KIE, Kigali, Rwanda.

Inyumba, A. 2009, Lecture to the Interdisciplinary Genocide Studies Center, Kigali, Rwanda, July 2009.

Jefremovas, V. 2002, Brickyards to graveyards: From production to genocide in Rwanda, State University of New York Press, Albany.

Kalisa, C. 2009, Scholar of aesthetic responses to the genocide, Personal Communication, Kigali, Rwanda, 15 July 2009.

Kilgour, M.A. 2007, 'US global compact and substantive equality for women: revealing a 'well hidden' mandate', Third World Quarterly, vol. 28, no. 4, pp. 751-73.

McCrummen, S. 2008, 'Women Run the Show in a Recovering Rwanda', The Washington Post, 27 October 2008. Retrieved from http://www.washingtonpost.com/wpdyn/content/article/2008/10/26/AR2008102602197.html

McGreal, C. 2008, 'We Are the Future', The Guardian UK, 17 December 2008. Retrieved from http://www.guardian.co.uk/world/2008/dec/17/rwanda-women-politics-human$\underline{\text { rights }}$ 
Masanja, V.G., De Silva, N.L., Uwizeye D. \& Niragire, F. 2010, Empowering Women in Research: The Case of the National University of Rwanda, Grafiska Punkten Malmö, Stockholm.

Mbabazi, H. 2012, 'Rwanda: Women’s post-genocidal success'. Visionews, accesssed 10/3/13, http://www.visionews.net/rwanda-women\%C2\%B4s-post-genocide-success/

Mucyo, J.D. 2009, Minister, National Commission for the Fight Against Genocide. Personal Interview. Kigali, Rwanda, July.

Mujawayo, E \& Belhaddad, S. 2004, SurVivantes. Editions de l'Aube, Le Moulin du Château, La Tour d'Aigues.

Mukankomeje, R. 2009, 'Une vie de lutte et de résistance: Témoignage de Rose Mukankomeje', Propos recueillis par Assumpta Mugiraneza. Penser et Ecrire l'Histoire du Genocide des Tutsi. Revue d'histoire de la Shoah, vol. 190, Janvier/Juin, pp. 357-365.

Musindarwezo, D. 2010, Women Can Do It (WCDI), Needs Assessment Workshop, Brainstorming with Stakeholders, Norwegian People’s Aid - Rwanda, 11 February 2010.

National Institute of Statistics of Rwanda 2006, Rwandan Demographic and Health Survey 2005, Kigali, Rwanda.

Nowrojee, B., Fleischman, J. \& DesForges A. 1996, Shattered Lives: Sexual Violence during the Rwandan Genocide and its Aftermath, Human Rights Watch/Africa Human Rights Watch Women's Rights Project, Fédération Internationale des Ligues des Droits de l'Homme. Human Rights Watch, September.

Nukurundo, L. 2010, Rwandan Initiative for Sustainable Development (RISD). Personal Interview, Kigali, Rwanda. 30 March 2010.

Paxton, P \& Hughes, M. M. 2007, Women, Politics and Power; A Global Perspective, Sage Publications, Thousand Oaks, CA.

Pearson, E. \& Powley E. 2008, 'Demonstrating legislative leadership: The introduction of Rwanda's Gender-Based Violence Bill.' The Rwanda Project. Institute for Inclusive Security, Hunt Alternatives Fund, 2008. http://www.huntalternatives.org/download/1078_rwanda_demonstrating_legislative_lea dership_updated_6_20_08.pdf

Personal Interviews (Anonymous). Kigali and Butare, Rwanda (February-May 2010).

Powley, E. 2005, 'Rwanda: Women hold up half the Parliament', International IDEA, pp.154-63. Retrieved from http://www.idea.int/publications/wip2/upload/Rwanda.pdf

Randell, S. 2009, Centre for Gender, Culture and Development 2009 Annual Report, Kigali Institute of Education, Kigali, Rwanda.

Republic of Rwanda Country Report 2009, Draft Evaluation of the Implementation of The Beijing Declaration and Program of Action Kigali, Ministry of Gender and Family Promotion, Kigali, Rwanda, October.

Ruboneka, S. 2009, Secrétaire Exécutive Nationale Collectifs Pro-FemmesTwese Hamwe. Collectif des Organisations Rwandaises de Promotion de la Femme, de la Paix et du Développement, Personal Interview, Kigali, Rwanda, July 2009.

Rutazibwa, P. 2009, Lecture to the Interdisciplinary Genocide Studies Center, Kigali, Rwanda, July.

Rwanda Association of University Women 2011, Listserve Messages (Anonymous). D-group RAUW mailing list, 8-10 June 2011.

Semujanga, J. 2003, Origins of the Rwandan Genocide, Humanity Books, Amherst, New York (Récits fondateurs du drame rwandais, 1998, l'Harmattan, Paris).

Spivak, Gayatri. 1988, “Can the Subaltern Speak?” in C. Nelson \& L. Grossberg (eds) Marxism and the Interpretation of Culture. Macmillan Education, Basingstoke. 
Stolberg, S.G. 2011, 'When it comes to scandal, girls won’t be boys', New York Times Week in Review, 11 June 2011.

Thomas, D. 1990, 'Intra-household resource allocation: An inferential approach', Journal of Human Resources, vol. 25, no. 4, pp. 635-64.

Trinh, T.M. 1982, dir. Reassemblage, Women Make Movies.

UNIFEM 2008, 'Rwandan women secure $56 \%$ of parliamentary seats in historic election result’ United Nations Development Fund for Women, 22 September 2008. Retrieved from http://www.unifem.org/news_events/story_detail.php?StoryID=736

Umulisa, H. 2009, Senator, Personal Interview, Kigali, Rwanda, 4 February 2010.

Uwineza, P. \& Pearson, E. 2009, 'Sustaining women's gains in Rwanda: The influence of indigenous culture and post-genocide politics’, Institute for Inclusive Security, Hunt Alternatives Fund.

World Bank Group, International Finance Corporation 2008, Voices of Women Entrepreneurs in Rwanda, World Bank, Washington D.C.

World Bank Group \& Vital Voices 2008, 'Weaving peace in Rwanda', Global Partnership Doing Business in Africa, World Bank, Washington D.C. 